\title{
A universal standard for health-promoting places. Example of assessment - on the basis of a case study of Rahway River Park
}

\author{
Monika Trojanowska \\ Department of Architecture and Urban Design; Faculty of Civil and Environmental Engineering and \\ Architecture; PBS University of Science and Technology in Bydgoszcz; \\ 7 prof. S.Kaliskiego Av., 85-796 Bydgoszcz, Poland; \\ monika.trojanowska@pbs.edu.pl (iD)0000-0001-8168-0746
}

\begin{abstract}
The purpose of this paper is to contribute to development of approaches to the evaluation of the design of public open green spaces (POS). This paper presents a universal standard for the design of health-promoting urban places. The standard is a conceptual framework which was developed after visiting over one hundred public parks and therapeutic gardens in Europe and the United States. The universal standard is a simple and effective tool that can be used by both professional designers and non-professionals to improve the health-promoting qualities of open green spaces. Rahway River Park, designed by Olmsted Brothers in 1925, serves as a case study.
\end{abstract}

Keywords: therapeutic landscapes, health-promoting places, universal standard of design, pattern of design

\section{Introduction}

The COVID-19 crisis highlighted human need to engage in open green spaces in cities. Current pressures due to urbanization have impacted the health and well-being of many people. Scientists confirm that everyday contact with nature is crucial for mental and physical health [1], [2]. Public parks can become places for mental and physical regeneration, physical activity, and social contacts. Green public spaces can act as therapeutic landscapes. Numerous researchers from various fields, e.g., environmental psychology, medicine, sociology, architecture, landscape design, and urban planning, have already described the main qualities of therapeutic landscapes [1], [2]. However, application of scientific approach is still needed [3]. The purpose of this study was to contribute to the development of methods of the evaluation of the design of public open green spaces (POS), particularly concerning therapeutic qualities of landscape for the promotion of the health of their users. The identified gap in knowledge results from the fact that existing quality assessment tools measure the physical activity infrastructure and 
sustainable solutions, while the therapeutic qualities of public open green spaces are rarely measured. This universal standard could be used to evaluate public open green spaces (POS), encompassing practical implications of design recommendations and the justification of specific choices to facilitate the promotion of public health. It was developed after performing scoping literature review and on-site observation of over a 100 of POS in various countries (France, Poland, Sweden, and the USA).

\section{Literature overview}

Gesler (1996) defined therapeutic landscapes as places where "physical and built environments, social conditions and human perceptions combine to produce an atmosphere which is conducive to healing [4]." However, individual perceptions of therapeutic landscapes may vary. Erwin Zube (1987) noticed that experience, personal utility functions, and social and cultural contexts were involved in shaping perceptions and responses to landscapes [5]. The landscape is 'a product of the human mind, and of material circumstances' [6]. Spaces that are perceived as therapeutic by one person could be experienced as unsettling by another [7]. However, there are examples of places well-known for their enduring potential to promote healing, for example, Lourdes in France, St. Anne de Beaupre in Quebec, Canada, Epidaurus in Greece, and Bama village in China [8]-[11]. In practice, the term therapeutic landscapes usually refers to specific places of established salutogenic reputation. The term health-affirming landscapes is more extensive and refers to more common places that unite the qualities of therapeutic landscapes to influence people's physical, mental and spiritual healing [12].

Both health-promoting places and therapeutic landscapes have therapeutic attributes. Though therapeutic landscapes are places which have an established reputation as well-known places of healing, the spiritual and symbolic aspects giving them an additional advantage. Material aspects alone can create human-friendly public spaces, but social conditions are needed to create health-promoting places, while spiritual and symbolic aspects further define therapeutic landscapes (Fig. 1).

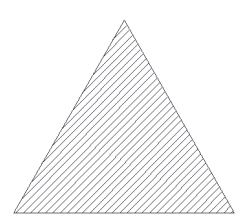

HUMAN FRIENDLY PUBLIC SPACE

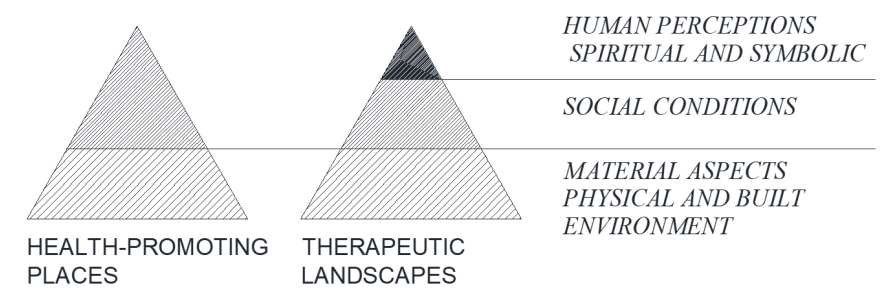

Fig. 1. Diagram showing the attributes directly related to therapeutic landscapes, overlapping with general qualities of human -friendly public spaces. Source: author, 2020

\subsection{Healing contact with nature}

Many researchers consider therapeutic landscapes as the presence of nature in the form of 'green' or 'blue' materialities [14]. Natural physical beauty is treated as a determinant of a salutogenic environment [15], [16]. Contact with nature can improve well-being and reduce stress level [17], [18]. Even watching nature can have a reassuring effect on patients before surgical operations and speeds up the post-surgery recovery [19]. Results of medical researches have shown that watching nature can stimulate significant physiological reactions within a few 
minutes, i.e. can cause changes in the electrical activity of the brain, blood pressure, heart, and the muscular system [19], p 91].

Therapeutic landscapes provide an opportunity to slow down and gain a sense of being present and attentive to the world [7]. Healing has been linked to the fact that people have opportunity to focus on something other than their current problems. Therefore, elements which engage attention, stimulate senses, and provoke interest are attributed to therapeutic landscapes [20]-[22]. The human mind needs an optimal level of complexity and thrives in a sensory-rich environment [17, 23-24]. An experience of overcoming controllable danger, i.e., climbing a mountain, or crossing a river, demands full focus and provides a feeling of accomplishment [22], [25].

\subsection{Social bonds}

The therapeutic properties of landscape depend on the social context of the place [4]. Even superficial social contacts can have a beneficial influence on human health [18], [26]-[30]. Green public spaces are conducive both to having strong relationship with the living environment, and to giving opportunities for social contacts [28]-[29], [31], [32]. Designers may have little impact on the social environment, but they can facilitate bringing people together. Jan Gehl has listed three categories of outdoor activities in the public areas: "necessary activities", "optional activities," and "social activities" (2011) [33]. "Necessary activities" are activities that the participants have no choice about, such as walking to school. "Optional activities" depend on the participants' desire to engage, such as going for a walk for pleasure. "Social activities" require engaging in contact with other people, such as children playing, friends talking, and passers-by briefly greeting each other. In a well-designed physical environment, the optional and social activities occur with high frequency. POS are places which can offer the possibility to restore mental health, as well as physical activity and social contacts.

\subsection{Mental restoration}

Salutogenic landscapes are often associated with places to rest in silence and solitude [19], [33]-[34]. Secluded gardens, which offer a sense of enclosure, have been mentioned in numerous researches over the years [20], [34], [35]. An interesting theoretical framework has been developed for the design of therapeutic gardens [36]. Many researchers have focused on the spiritual meaning of healing and the positive relationship between spiritual activity and health and well-being [14], [21], [37].

\subsection{The importance of physical activity}

Greenspace exposure is positively associated with moderate to vigorous physical activity and physical activity is directly linked to promotion of health and well-being [37]. A team of Japanese doctors led by Takehito Takano (2002) has already proven that a well-designed system of green areas encouraging walking is a factor which can directly affect the longevity of senior citizens [38]. According to Gibson's theory, affordances of an environment are what it offers to users (2014) [39]. Affordances are all the possible actions that may occur in a place, and the actions needed to be discoverable by the user. The promotion of health is one of the possible affordances of public open green spaces (POS) [41]. With careful design, healing affordances should be easily perceptible to users and public open green spaces would "tell people what to do with them", i.e., rest in silence and solitude, observe wildlife and other people's activities, 
engage in socializing with other people, play sports, etc. A recent study demonstrated the positive effect of a sensory garden on 'apparently well' people in the workplace [42].

\subsection{Current frameworks for classifying parks}

In this study, places are defined as public open green spaces (POS). POS are classified in the literature in many ways. The classification schemes are based on the size and distance to potential users, as well as their primary functions [42], [43]. A comprehensive typology was proposed by the Government of Western Australia (2012). It identifies three primary types of open spaces according to function (primary use and expected activities): recreation spaces, sport spaces, and nature spaces, as well as four categories based on catchment hierarchy (typical size and how far a user might travel to visit the site), which includes: local open space, neighbourhood open space, district open space, and regional open space.

\subsection{Measure-oriented approaches to POS design}

There are tools available for the assessment of a park users' physical activity levels, e.g., SoPARC, SoPLAY, or EARPS. These can be used to foster the quality and for improvement of the POS. However, they do not include the evaluation of restorative qualities. Thus, despite growing attention to this topic, there is a lack of specific tools that enable a structured analysis of therapeutic qualities of the POS.

\section{Methods}

This long-term study began in 2001 with the aim of systematizing the qualities of therapeutic landscapes. It was driven by the objective to develop a universal standard of health-promoting places which could be implemented in various cultural settings.

The study was carried out by the author on over a hundred $(n=125)$ public open green spaces (POS) and private therapeutic gardens in Europe and the United States. The choice of the cities in this study resulted from personal experience. The list mostly includes cities where the author has lived, worked or studied. Therefore, it includes well-known parks in New York and Paris, as well as several parks in Poland. A full list of the parks and gardens is presented in Table 2. Public parks and therapeutic gardens visited during the field research. The POS were visited frequently, on multiple occasions, which allowed for repeated observations in different time frames to give a broader and deeper perspective on users' behaviour.

The aim was to visit and assess not only famous parks, but also less well-known places which have been referred to as favourite places of recreation by residents of the neighbourhoods. These human perceptions were treated as a social proof of the therapeutic qualities of a landscape.

This study has concentrated on determining what has worked well in the parks visited. The time spent in each of the public parks ranged from two to multiple hours. The length of stay usually depended on the size of a park and the number of its attributes. The data collection methods included study walks exploring the entire park territory, observation of users' activities and preferences, as well as unstructured interviews with park users. 
Table 1. Public parks and therapeutic gardens visited during the field research

\begin{tabular}{|c|c|c|c|}
\hline Country & $\begin{array}{l}\text { City and } \\
\text { Vicinities }\end{array}$ & $\begin{array}{l}\text { Number of } \\
\text { Parks Visited }\end{array}$ & Public Parks and Therapeutic Gardens \\
\hline USA & New York & 12 & $\begin{array}{c}\text { Central Park, Paley Park, Bryant Park, Gramercy Park, Madison Square } \\
\text { Park, Union Square Park, Washington Square Park, Stuyvesant Square } \\
\text { Park, John Russel Wheeler Park in Linden, NJ, Rahway River Park, } \\
\text { Cheesequake State Park, Rutgers University Gardens }\end{array}$ \\
\hline France & Paris & 50 & $\begin{array}{l}\text { Bois de Boulogne, Bois de Vincennes, Parc André Citroën, Jardin } \\
\text { d'Acclimatation, Jardin Bagatelle, Parc de Belleville, Parc de Bercy, } \\
\text { Parc George-Brassens, Parc de la Butte-du-Chapeau-Rouge, Parc des } \\
\text { Buttes-Chaumont, Parc Floral, Parc Kellermann, Parc Monceau, Parc } \\
\text { Montsouris, Parc de la Villette, Jardin Atlantique, Jardin de l’UNESCO, } \\
\text { Jardin du Luxembourg, Jardins du Palais Royal, Jardin du Trocadéro, } \\
\text { Jardin des Tuileries, Jardin des Plantes, Jardin Villemin, Promenade } \\
\text { plantée, Promenade des Berges de la Seine, Square de Batignolles, } \\
\text { Parc Martin Luther King, Grand Parc de Docks de Saint Ouen, Jardin } \\
\text { thérapeutique- Grain de Vie Hôpital Curie, Jardin de L'Ile Seguin, Parc } \\
\text { de Billancourt, Jardin Catherine Labouré, Square Boucicaut, Jardin Tino } \\
\text { Rossi, Jardin de Reuilly, Square Jean XXIII, Square R.Viviani, Square } \\
\text { du Vert Galant, Square Lois XIII, Jardin de la Valée Suisse, Square } \\
\text { L-Frapié, Jardin des Fougères, Square E.-Fleury, Square du Serment- } \\
\text { de-Koufra, Parc des impressionnistes - Clichy, Parc de Sceaux, Parc } \\
\text { de Versailles, Parc de Fontainebleau, Parc de Chantilly, Parc de Saint } \\
\text { Cloud, Parc Du Chemin De L'Ile }\end{array}$ \\
\hline Sweden & Stockholm & 3 & Djurgarden, Trygghansa, Kronobergsparken \\
\hline \multirow{4}{*}{ Poland } & Poznań & 19 & $\begin{array}{c}\text { Botanical Garden, Park Fryderyka Chopina, Park Cytadela, Park } \\
\text { Czarneckiego, Park Jana Kasprowicza, Park Karola Kurpińskiego, Park } \\
\text { Karola Marcinkowskiego, Park Adama Mickiewicza, Park Stanisława } \\
\text { Moniuszki, Park Sołacki, Park Tysiąclecia, Park Thomasa W. Wilsona, } \\
\text { Park Henryka Wieniawskiego, Park Stare Koryto Warty, Spatial } \\
\text { Orientation Park in Owińska, Malta, Park Wodziczki, Park Szelągowski, } \\
\text { Park Zwycięstwa }\end{array}$ \\
\hline & Cracow & 16 & $\begin{array}{c}\text { Botanical Garden, Planty, Bulwary Wiślane, Park Strzelecki, Park } \\
\text { Tadeusza Kościuszki, Park Henryka Jordana, Park Ludwika Decjusza, } \\
\text { Park Wojciecha Bednarskiego, Park Wincentego a Paulo, Park } \\
\text { Lotników Polskich, Stanislaw Lem Garden of Experiences, Biblical } \\
\text { Garden, Proszowice, Therapeutic Garden, Rabka, Park Zdrojowy, } \\
\text { Rabka, Kalwaria Zebrzydowska, Archeological Museum }\end{array}$ \\
\hline & Bydgoszcz & 10 & $\begin{array}{c}\text { Botanical Garden, Park Dolina Pięciu Stawów, Park Balaton, } \\
\text { Park in Myslęcinek, Park im. Kazimierza Wielkiego, Park Jana } \\
\text { Kochanowskiego, Park Henryka Dąbrowskiego, Park Księżycowy, Park } \\
\text { Zbigniewa Załuskiego, Park in Ostromecko }\end{array}$ \\
\hline & Gdańsk & 15 & $\begin{array}{c}\text { Park Oliwski, Park Oruński, Park Kuźniczki, Park Haffnera, Park } \\
\text { Steffensów, Park Ronalda Regana, Medicinal Plant Garden, Park } \\
\text { Haffnera, Sopot, Park Kiloński, Gdynia, Kamienna Góra, Gdynia, } \\
\text { Park im. A. Majkowskiego, Wejherowo, Kalwaria, Wejherowo, Tricity } \\
\text { Landscape Park, Park Starowiejski, Rumia }\end{array}$ \\
\hline
\end{tabular}

\section{Findings and analysis}

During this study, a conceptual framework for a universal standard of health affirming places was developed in an iterative process. The first draft was gradually amended with new findings. The final draft of the standard is presented in Table 2. A universal standard for health-promoting urban places. The qualities were divided into five categories: 1. Sustainability, 2. Accessibility, 3. Amenities, 4. Design and 5. Placemaking. Those categories were used to organize the qualities of therapeutic landscapes in a legible manner. 
Table 2. A universal standard for health-promoting urban places. Source: updated by the author [44]-[46]

1. SUSTAINABILITY 2. ACCESSIBILITY 3. AMENITIES

\begin{tabular}{|c|c|}
\hline 1.1.Place & 2.1. Distance to park \\
\hline Area & 2.2. Sidewalk Infra- \\
\hline Location & structure- \\
\hline Surrounding urban & Width of sidewalk \\
\hline $\begin{array}{l}\text { pattern } \\
\text { 1.2. Environmental } \\
\text { characteristics }\end{array}$ & $\begin{array}{l}\text { Evenness of surface } \\
\text { Lack of obstructions } \\
\text { Slope }\end{array}$ \\
\hline Soil quality & Sufficient drainage \\
\hline Water quality & 2.3. General condi- \\
\hline Air quality & tions of walkways \\
\hline Noise level & Maintenance \\
\hline $\begin{array}{l}\text { Forms of natural } \\
\text { protection }\end{array}$ & $\begin{array}{l}\text { Overall aesthetics } \\
\text { Street art }\end{array}$ \\
\hline $\begin{array}{l}\text { Green and Blue Infra- } \\
\text { structure }\end{array}$ & $\begin{array}{l}\text { Sufficient seating } \\
\text { Perceived safety }\end{array}$ \\
\hline $\begin{array}{l}\text { 1.3. Biodiversity } \\
\text { protection }\end{array}$ & $\begin{array}{l}\text { Buffering from traffic } \\
\text { Street activities }\end{array}$ \\
\hline Parts of open green & Vacant lots \\
\hline space not available to & 2.4. Traffic \\
\hline visitor & Speed \\
\hline Native plants & Volume \\
\hline Native animals & Number and safety of \\
\hline Natural maintenance & crossings \\
\hline methods & Stop signs \\
\hline $\begin{array}{l}\text { 1.4. Sustainable water } \\
\text { management }\end{array}$ & $\begin{array}{l}\text { On-street parking } \\
\text { 2.5. User Experience }\end{array}$ \\
\hline Rainwater infiltration & Air quality \\
\hline Irrigation with non-pota- & Noise level \\
\hline ble water & Sufficient lighting \\
\hline $\begin{array}{l}\text { 1.5. Parks of Second } \\
\text { (New) Generation }\end{array}$ & $\begin{array}{l}\text { Sunshine and shade } \\
\text { Visibility of nearby }\end{array}$ \\
\hline 1.6. Urban metabolism & building \\
\hline $\begin{array}{l}\text { 1.7. Ecological energy } \\
\text { sources }\end{array}$ & $\begin{array}{l}\text { 2.6. Public transport } \\
\text { stops } \\
\text { 2.7. Sufficient Parking }\end{array}$ \\
\hline
\end{tabular}
Green open space

Presence of water sunshade

Places to rest in

3.2. Promotion of ities

Sports and recreaAddressing the needs of people with disabilities

\subsection{Catering for} basic needs nance, etc.) Shelter

Restrooms

Drinking water or in the closest vicinity)
4. DESIGN 5. PLACEMAKING

\subsection{Psychological and physical regeneration \\ 4.1. Archi- tectural design}

Natural Landscapes Places to rest in the

Human scale Focal points and landmarks

Structure of interior connections silence and solitude Physical Activtional infrastructure Community gardens

Safety and security (presence of guards, cleanliness, mainte-

Places to sit and rest

Food (possibility to buy food in the park

Framed views

Long vistas

(Extent)

Pathways with views

Invisible parts

of the scenery

(Vistas which

engage the imagination)

Possibility to

watch other

people

Possibility to

see wildlife

4.2. Saluto-

genic

design

Optimal levels

of complexity

Engaging

features

Risk

Mystery/

Fascination

Movement

\subsection{Sensory}

stimuli

design

Sensory stimuli: Sight

Sensory stimuli: Hearing

Sensory stimuli: Smell

Sensory stimuli: Touch

Sensory stimuli: Taste

Sensory path
5.1. Enhancement of Social Contacts

Organization of events

Meeting places for

groups

\subsection{Human percep-} tion-spiritual \& symbolic

Sacred places

Works of Art

Monuments

Culture and connections to the past Thematic gardens Personalization 5.3. Community Engagement Personalising the architectural process Participation of all stakeholders, including inhabitants and users Determining the rules of conduct and self- management Space for social contacts third places fourth places 


\subsection{Proposed methodology of assessment with the universal standard for health-promoting urban places}

Each of the five categories includes sub-categories and individual attributes. The final draft of the universal standard of design for health-promoting places can be used for binary or detailed assessment. The binary assessment has only 2 categories $(0 ; 1)$ :

0 - No, not observed.

1 - Yes, satisfactory.

The maximum number of points for binary assessment are presented in Table 3. Maximum number of points for binary assessment. Simple manual calculation method was used to add the points. A customized Excel spreadsheet was used to verify the results.

The detailed assessment required a written explanation why the researcher thought that the attribute was present, satisfactory, and worthy granting a point.

Table 3. Maximum number of points for binary assessment. Source: author

\begin{tabular}{ll}
\hline & MAXIMUM NUMBER OF POINTS \\
\hline TOTAL & 91 \\
\hline CATEGORIES & 15 \\
\hline 1. SUSTAINABILITY & Category with no points \\
\hline 1.1.Place & 6 \\
\hline 1.2.Environmental characteristics & 4 \\
\hline 1.3.Biodiversity protection & 2 \\
\hline 1.4.Sustainable water management & 1 \\
\hline 1.5.Parks of Second (New) Generation & 1 \\
\hline 1.6.Urban metabolism & 1 \\
\hline 1.7.Ecological energy sources & 26 \\
\hline 2. ACCESSIBILITY & 1 \\
\hline 2.1.Distance to park & 5 \\
\hline 2.2.Sidewalk Infrastructure & 8 \\
\hline 2.3.General conditions of walkways & 5 \\
\hline 2.4.Traffic & 5 \\
\hline 2.5.User Experience & 1 \\
\hline 2.6.Public transport stops & 1 \\
\hline 2.7. Sufficient Parking & 15 \\
\hline 3. AMENITIES & 5 \\
\hline 3.1.Psychological and physical regeneration & 4 \\
\hline 3.2.Promotion of Physical Activities & 6 \\
\hline 3.3.Catering for basic needs & 21 \\
\hline 4. DESIGN & 10 \\
\hline 4.1.Architectural design & 5 \\
\hline 4.2.Salutogenic design & 6 \\
\hline 4.3.Sensory stimuli design & 14 \\
\hline 5. PLACEMAKING & 2 \\
\hline 5.1.Enhancement of Social Contacts & 6 \\
\hline 5.2.Human perception -spiritual \& symbolic & 6 \\
\hline 5.3.Community Engagement & \\
\hline & \\
\hline
\end{tabular}


Proposed methodology for assessment of individual categories was provided in tables 4-8. Each of the tables provides the number of points possible to gain in each category for every individual feature as well as general description of requirements. For better clarity, the results of the assessment were grouped into five tables (Tables 4-8).

The standard consists of five categories.

\section{Sustainability}

This section is dedicated to assessments of the general characteristics of a local area (table 4). In the case of existing parks, most of these characteristics, e.g., place: area, location, surrounding urban patterns, are beyond the control of park designers. However, at the planning stage, decisions about the location of a park can be discussed. Design criteria should always be oriented on the location, its environmental characteristics, and landscape values.

Environmental characteristics (biodiversity, soil, water, and air quality) can significantly improve or undermine the therapeutic qualities of a location [46], [47].

This section includes all the aspects relating to the sustainable design of public parks: the protection of native fauna and flora and enabling the natural infiltration of rainwater and harvesting it for irrigation. Sustainable management of water and soil require special maintenance techniques and may limit the choice of plants, but it is beneficial for both our planet and people.

Table 4. Draft table for sustainability assessment (right column - number of points). Source: author

\begin{tabular}{|c|c|c|}
\hline 1. SUSTAINABILITY & & 15 \\
\hline 1.1. Place & & Category with no points \\
\hline Area & Provide detailed description & Category with no points \\
\hline Location & Provide detailed description & Category with no points \\
\hline Surrounding urban pattern & Provide detailed description & Category with no points \\
\hline 1.2. Environmental characteristics & & 6 \\
\hline Soil quality & $\begin{array}{l}\text { Sufficient for recreational use. } \\
\text { No visible traces of pollution }\end{array}$ & 1 \\
\hline Water quality & $\begin{array}{l}\text { Sufficient for recreational use. } \\
\text { No visible traces of pollution }\end{array}$ & 1 \\
\hline Air quality & $\begin{array}{l}\text { Sufficient for recreational use. } \\
\text { No visible traces of pollution }\end{array}$ & 1 \\
\hline Noise level & No nuisance to moderate noise nuisance & 1 \\
\hline Forms of natural protection & Are there any forms of natural protection? & 1 \\
\hline Green and Blue Infrastructure & $\begin{array}{l}\text { Does the park form part of the green and blue infra- } \\
\text { structure? If YES - } 1 \text { point }\end{array}$ & 1 \\
\hline 1.3. Biodiversity protection & & 4 \\
\hline $\begin{array}{l}\text { Parts of open green space not available to } \\
\text { visitors }\end{array}$ & $\begin{array}{l}\text { Are there any secluded areas for biodiversity } \\
\text { protection? }\end{array}$ & 1 \\
\hline Native plants & Planting with native species & 1 \\
\hline Native animals & $\begin{array}{l}\text { Are there native species present in the park? If YES } \\
-1 \text { point }\end{array}$ & 1 \\
\hline Natural maintenance methods & $\begin{array}{l}\text { What kind of methods of maintenance are used? If } \\
\text { only natural }-1 \text { point }\end{array}$ & 1 \\
\hline 1.4. Sustainable water management & & 2 \\
\hline Rainwater infiltration & Porous, permeable surfaces. & 1 \\
\hline Irrigation with non-potable water & If irrigation with non-potable water is used -1 point & \\
\hline \multirow[t]{2}{*}{ 1.5. Parks of Second (New) Generation } & & 1 \\
\hline & $\begin{array}{l}\text { Can the park be considered as a park of second (new) } \\
\text { generation }\end{array}$ & 1 \\
\hline \multirow[t]{2}{*}{ 1.6. Urban metabolism } & & 1 \\
\hline & Is waste segregation facilitated? If YES -1 point & 1 \\
\hline \multirow[t]{2}{*}{ 1.7. Ecological energy sources } & & 1 \\
\hline & $\begin{array}{l}\text { Are there ecological energy sources used in the park? } \\
\text { If YES - } 1 \text { point }\end{array}$ & 1 \\
\hline
\end{tabular}




\section{Accessibility}

In the case of health-affirming urban places, the qualities of the entrances and pedestrian routes leading to the park are as important as the design of the park itself (table 5). This category could be called the 'walkability assessment' [47]. Universal accessibility, understood as addressing the needs of people with disabilities, is directly linked to the therapeutic potential of a park and the possibilities for the promotion of health.

Table 5. draft table for accessibility assessment (right column - number of points). Source: author

\begin{tabular}{lll}
\hline 2. ACCESSIBILITY & & 26 \\
\hline 2.1.Distance to park & & $1 / 1$ \\
\hline & Is it possible to walk to park? If YES - 1 point & 1 \\
\hline 2.2.Sidewalk Infrastructure & & 5 \\
\hline Width of sidewalk & Sufficient for walking & 1 \\
\hline Evenness of surface & Sufficient for walking & 1 \\
\hline Lack of obstructions & Lack of obstructions & 1 \\
\hline Slope & Flat, no significant slope & 1 \\
\hline Sufficient drainage & Sufficient for walking & 1 \\
\hline 2.3.General conditions of walkways & The park is perceived as clean. No visible traces of litter & 8 \\
\hline Maintenance & The park is perceived as aesthetically pleasing & 1 \\
\hline Overall aesthetics & The park is perceived as a safe place & 1 \\
\hline Street art & Multiple benches & 1 \\
\hline Sufficient seating & The park is perceived as a safe place & 1 \\
\hline Perceived safety & Sufficient & 1 \\
\hline Buffering from traffic & Occasional events, organised or spontaneous & 1 \\
\hline Street activities & No vacant lots adjacent to park. The park is perceived as a safe & 1 \\
\hline Vacant lots & place & 1 \\
\hline 2.4.Traffic & & 5 \\
\hline Speed & Slow. The park is perceived as a safe place & 1 \\
\hline Volume & Moderate. The park is perceived as a safe place & 1 \\
\hline Number and safety of crossings & Numerous possibilities for crossing the street & 1 \\
\hline Stop signs & Yes. The park is perceived as a safe place & 1 \\
\hline On-street parking & Yes. The park is perceived as a safe place & 1 \\
\hline 2.5.User Experience & & 5 \\
\hline Air quality & Good. The park is perceived as a safe place & 1 \\
\hline Noise level & Moderate. The park is perceived as a safe place & 1 \\
\hline Sufficient lighting & Yes, numerous lamps. The park is perceived as a safe place & 1 \\
\hline Sunshine and shade & Yes. Trees provide shade & 1 \\
\hline Visibility of nearby buildings & Yes. The park is perceived as a safe place & 1 \\
\hline 2.6.Public transports stops & & 1 \\
\hline 2.7.Sufficient Parking & There are bus stops near the park & 1 \\
\hline & & 1 \\
\hline & & 1 \\
\hline
\end{tabular}

\section{Amenities}

This section concerns sports and leisure equipment, as well as park facilities related to promoting physical and mental rejuvenation, encouragement of physical activities and moderate social contacts (table 6). A fourth category relates to the basic needs of park users, such as 
shelter, restrooms, drinking water, food, and places to sit and rest. It also includes properties that bring a sense of safety and security: the presence of guards, cleanliness, and maintenance.

Table 6. Draft table for amenities assessment. (right column - number of points). Source: author

\begin{tabular}{|c|c|c|}
\hline 3. AMENITIES & & 15 \\
\hline 3.1.Psychological and $p$ & hysical rejuvenation & 5 \\
\hline Natural landscapes & $\begin{array}{l}\text { Are there places which give an impression of a pristine natural landscape? } \\
\text { If YES - } 1 \text { point }\end{array}$ & 1 \\
\hline Green open space & Are there any green open spaces? If YES - 1 point & 1 \\
\hline Presence of water & Is there any water in the park? If yes, in what form? If YES -1 point & 1 \\
\hline $\begin{array}{l}\text { Places to rest in the sun } \\
\text { and shadow }\end{array}$ & Multiple places to sit and rest in the sun and shadow & 1 \\
\hline $\begin{array}{l}\text { Places to rest in silence } \\
\text { and solitude }\end{array}$ & Multiple benches to rest and enjoy silence and solitude & 1 \\
\hline 3.2.Physical Activity Pr & omotion & 4 \\
\hline Sports infrastructure & $\begin{array}{l}\text { Are there any sports infrastructure in the park? Is it satisfactory for vari- } \\
\text { ous age groups? If YES }-1 \text { point }\end{array}$ & 1 \\
\hline $\begin{array}{l}\text { Recreational infra- } \\
\text { structure }\end{array}$ & Is it satisfactory for various age groups? If YES - 1 point & 1 \\
\hline Community gardens & Are there any community gardens? If YES - 1 point & 1 \\
\hline $\begin{array}{l}\text { Addressing the needs of } \\
\text { people with disabilities }\end{array}$ & $\begin{array}{l}\text { Are the pathways wide and even? } \\
\text { Is the park area accessible? If YES - } 1 \text { point }\end{array}$ & 1 \\
\hline 3.3.Catering for basic $n$ & leeds & 6 \\
\hline
\end{tabular}

Safety and security (presence of guards, cleanliness, mainte-

nance, etc.)

\begin{tabular}{lll}
\hline Places to sit and rest & Are there any? Are they satisfactory? If YES - 1 point & 1 \\
\hline Shelter & Are there any? Are they satisfactory? If YES - 1 point & 1 \\
\hline Restrooms & Are there any? Are they satisfactory? If YES - 1 point & 1 \\
\hline Drinking water & Are there any? Are they satisfactory? If YES - 1 point & 1 \\
\hline $\begin{array}{l}\text { Food (possibility to buy } \\
\text { food in the park or close } \\
\text { vicinities) }\end{array}$ & Are there any? Are they satisfactory? If YES - 1 point & 1 \\
\hline
\end{tabular}

\section{Design}

This section encompasses the distribution of functions within the park space and the organization of its grid of connections (table 7). It is important that the design of a park is comprehensible and the composition harmonious. Some attributes are important when it comes to engaging the interest of users, such as mystery, risk, and movement. A separate category is dedicated to multi-sensory stimuli and sensory paths. 
Table 7. Draft table for design assessment (right column - number of points). Source: author

\begin{tabular}{|c|c|c|}
\hline 4. DESIGN & & 21 \\
\hline 4.1.Architectural design & & 10 \\
\hline Human scale & Is the design respecting the human scale? If YES - 1 point & 1 \\
\hline $\begin{array}{l}\text { Architectural variety of } \\
\text { urban environment }\end{array}$ & $\begin{array}{l}\text { Is the Architectural variety observed in the surrounding urban environ- } \\
\text { ment? If YES - } 1 \text { point }\end{array}$ & 1 \\
\hline $\begin{array}{l}\text { Focal points and } \\
\text { landmarks }\end{array}$ & Are there any clear landmarks? If YES - 1 point & 1 \\
\hline $\begin{array}{l}\text { Structure of interior } \\
\text { connections }\end{array}$ & Is there a clear structure of interior connections? If YES - 1 point & 1 \\
\hline Framed views & Are there any? Are they satisfactory? If YES - 1 point & 1 \\
\hline Long vistas (Extent) & Are there any? Are they satisfactory? If YES - 1 point & 1 \\
\hline Pathways with views & Are there any? Are they satisfactory? If YES - 1 point & 1 \\
\hline $\begin{array}{l}\text { Invisible parts of the } \\
\text { scenery (Vistas which } \\
\text { engage the imagination) }\end{array}$ & Are there any? Are they satisfactory? If YES - 1 point & 1 \\
\hline $\begin{array}{l}\text { Possibility to observe } \\
\text { other people }\end{array}$ & $\begin{array}{l}\text { Are there any possibilities to observe other people? Are they satisfac- } \\
\text { tory? If YES - } 1 \text { point }\end{array}$ & 1 \\
\hline $\begin{array}{l}\text { Possibility to observe } \\
\text { animals }\end{array}$ & $\begin{array}{l}\text { Are there any possibilities to observe animals? Are they satisfactory? If } \\
\text { YES }-1 \text { point }\end{array}$ & 1 \\
\hline 4.2.Salutogenic design & & 5 \\
\hline $\begin{array}{l}\text { Optimal levels of } \\
\text { complexity }\end{array}$ & $\begin{array}{l}\text { Are there any features in this category? Are they satisfactory? If YES - } \\
1 \text { point }\end{array}$ & 1 \\
\hline Engaging features & $\begin{array}{l}\text { Are there any features in this category? Are they satisfactory? If YES - } \\
1 \text { point }\end{array}$ & 1 \\
\hline Controlled Risk & $\begin{array}{l}\text { Are there any features in this category? Are they satisfactory? If YES - } \\
1 \text { point }\end{array}$ & 1 \\
\hline Mystery/Fascination & $\begin{array}{l}\text { Are there any features in this category? Are they satisfactory? If YES - } \\
1 \text { point }\end{array}$ & 1 \\
\hline Movement & $\begin{array}{l}\text { Are there any features in this category? Are they satisfactory? If YES - } \\
1 \text { point }\end{array}$ & 1 \\
\hline 4.3.Sensory stimuli design & & 6 \\
\hline Sensory stimuli: Sight & $\begin{array}{l}\text { Are there any features in this category? Are they satisfactory? If YES - } \\
1 \text { point }\end{array}$ & 1 \\
\hline Sensory stimuli: Hearing & $\begin{array}{l}\text { Are there any features in this category? Are they satisfactory? If YES - } \\
1 \text { point }\end{array}$ & 1 \\
\hline Sensory stimuli: Smell & $\begin{array}{l}\text { Are there any features in this category? Are they satisfactory? If YES - } \\
1 \text { point }\end{array}$ & 1 \\
\hline Sensory stimuli: Touch & $\begin{array}{l}\text { Are there any features in this category? Are they satisfactory? If YES - } \\
1 \text { point }\end{array}$ & 1 \\
\hline Sensory stimuli: Taste & $\begin{array}{l}\text { Are there any features in this category? Are they satisfactory? If YES - } \\
1 \text { point }\end{array}$ & 1 \\
\hline Sensory path & $\begin{array}{l}\text { Are there any features in this category? Are they satisfactory? If YES - } \\
1 \text { point }\end{array}$ & 1 \\
\hline
\end{tabular}

\section{Placemaking}

The most important feature of a human-friendly landscape is a sense of safety and belonging of all users (table8). Public parks offer an ideal possibility for various kinds of social contacts for people from usually isolated and disadvantaged social groups (the elderly, disabled, etc.). Placemaking is related to the popularity of a park. Here, the attributes which 
relate to the promotion of moderate social contacts and human perceptions have been combined into one category.

Table 8. Draft table for placemaking assessment (right column - number of points). Source: author

\begin{tabular}{|c|c|c|}
\hline \multicolumn{2}{|l|}{ 5. PLACEMAKING } & 14 \\
\hline \multicolumn{2}{|c|}{ 5.1.Social Contact Enhancement } & 2 \\
\hline Organization of events & $\begin{array}{l}\text { Are there any events organised? Are they popular/ frequented? If YES - } \\
1 \text { point }\end{array}$ & 1 \\
\hline $\begin{array}{l}\text { Meeting places for } \\
\text { groups }\end{array}$ & Are there any? Are they satisfactory? If YES - 1 point & 1 \\
\hline \multicolumn{2}{|c|}{ 5.2.Human perception - spiritual \& symbolic } & 6 \\
\hline Sacred places & $\begin{array}{l}\text { Are there any features in this category? Are they satisfactory? If YES - } \\
1 \text { point }\end{array}$ & 1 \\
\hline Works of Art & $\begin{array}{l}\text { Are there any features in this category? Are they satisfactory? If YES - } \\
1 \text { point }\end{array}$ & 1 \\
\hline Monuments & $\begin{array}{l}\text { Are there any features in this category? Are they satisfactory? If YES - } \\
1 \text { point }\end{array}$ & 1 \\
\hline $\begin{array}{l}\text { Culture and connections } \\
\text { to the past }\end{array}$ & $\begin{array}{l}\text { Are there any features in this category? Are they satisfactory? If YES - } \\
1 \text { point }\end{array}$ & 1 \\
\hline Thematic gardens & $\begin{array}{l}\text { Are there any features in this category? Are they satisfactory? If YES - } \\
1 \text { point }\end{array}$ & 1 \\
\hline Personalisation & $\begin{array}{l}\text { Are there any features in this category? Are they satisfactory? If YES - } \\
1 \text { point }\end{array}$ & 1 \\
\hline \multicolumn{2}{|c|}{ 5.3.Community Engagement } & 6 \\
\hline $\begin{array}{l}\text { Personalising the archi- } \\
\text { tectural process }\end{array}$ & $\begin{array}{l}\text { Are the persons responsible for the design, construction and management } \\
\text { known to the public? If YES - } 1 \text { point }\end{array}$ & 1 \\
\hline $\begin{array}{l}\text { Participation of all } \\
\text { stakeholders, including } \\
\text { inhabitants and users }\end{array}$ & $\begin{array}{l}\text { Do all stakeholders, including inhabitants and users have a real influence } \\
\text { on the design and maintenance through participatory process? If YES - } \\
1 \text { point }\end{array}$ & 1 \\
\hline $\begin{array}{l}\text { Determining the rules } \\
\text { of conduct and self- } \\
\text { management }\end{array}$ & $\begin{array}{l}\text { Are there any rules of conduct and self-management established and } \\
\text { publicly available? Are there any information boards with rules of } \\
\text { conduct and self-management placed in the public space? Were the rules } \\
\text { of conduct and self-management established in a participatory process? } \\
\text { Do all stakeholders including inhabitants and users agree upon the } \\
\text { common rules of conduct and self-management? If YES - } 1 \text { point }\end{array}$ & 1 \\
\hline Space for social contacts & $\begin{array}{l}\text { Is there an inclusive, accessible space for social contacts available to all? } \\
\text { If YES - } 1 \text { point }\end{array}$ & 1 \\
\hline third places & Can it be the third place for anyone? If YES - 1 point & 1 \\
\hline fourth places & Can it be the fourth place for anyone? If YES - 1 point & 1 \\
\hline
\end{tabular}




\section{Case study of Rahway River Park, NJ, USA}

Rahway River Park in Union County, NJ, USA (Fig. 2) was chosen as a case study to demonstrate the way of using the universal standard. This park is well-documented in the history of landscape design and well-known internationally, as it was designed by the Olmsted brothers. Firstly, this place was recommended to the author by regular parkgoers who described it as a good place to disengage from the problems of everyday life. One of them described this experience: "After one hour spent in the park, the weariness of the daywork in front of the computer disappears. I come back home from this park with new energy." The research question was what makes this park a health-promoting place in terms of the architectural and landscape design? (Fig. 2-10).

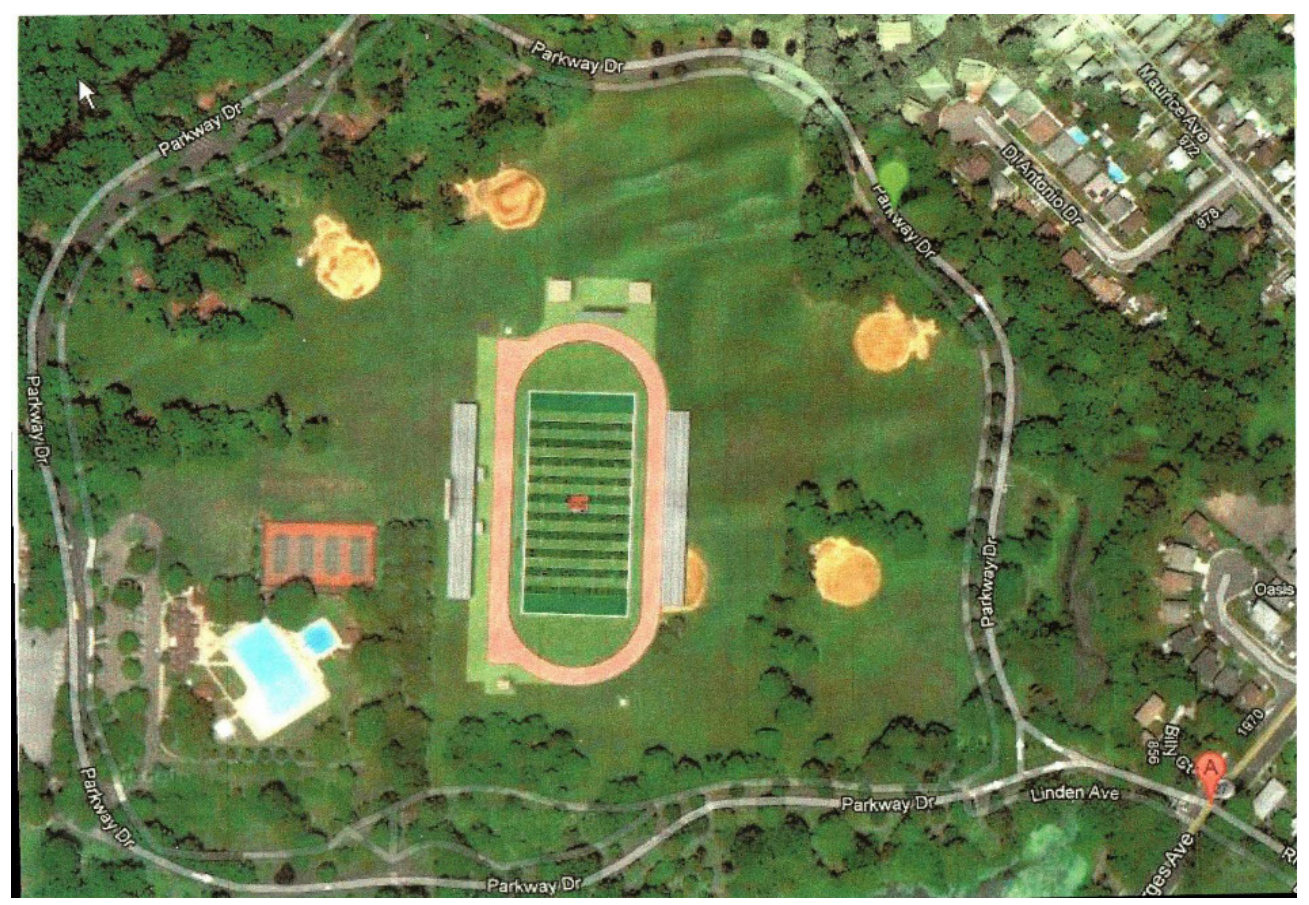

Fig. 2. Rahway River Park as seen from above. Source [48] 

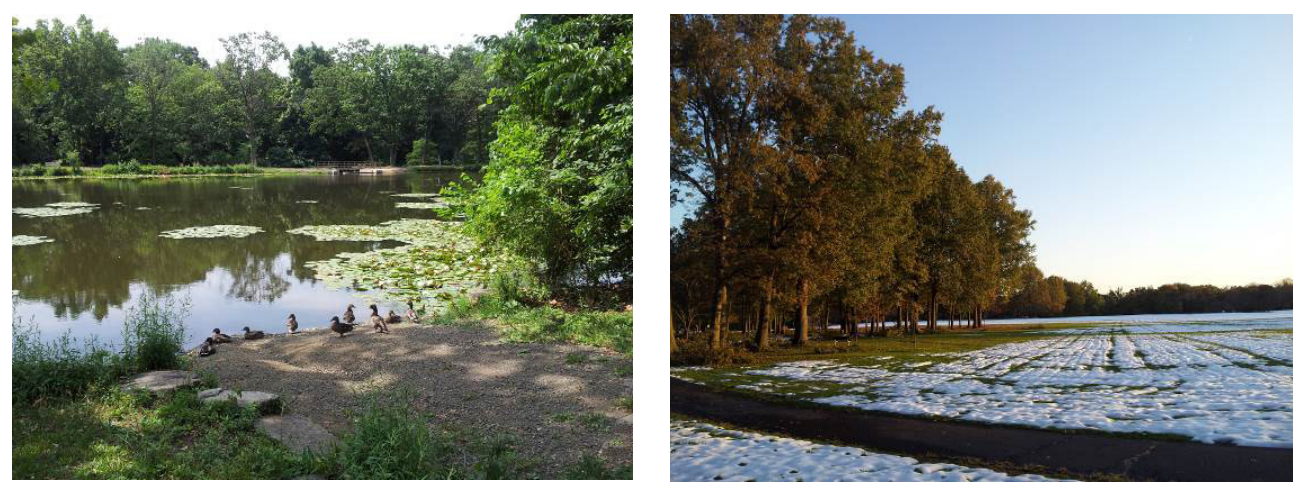

Fig. 3. Rahway River Park - wildlife. Source: author's photography

Fig. 4. Rahway River Park in the winter - play areas. Source: author's photography
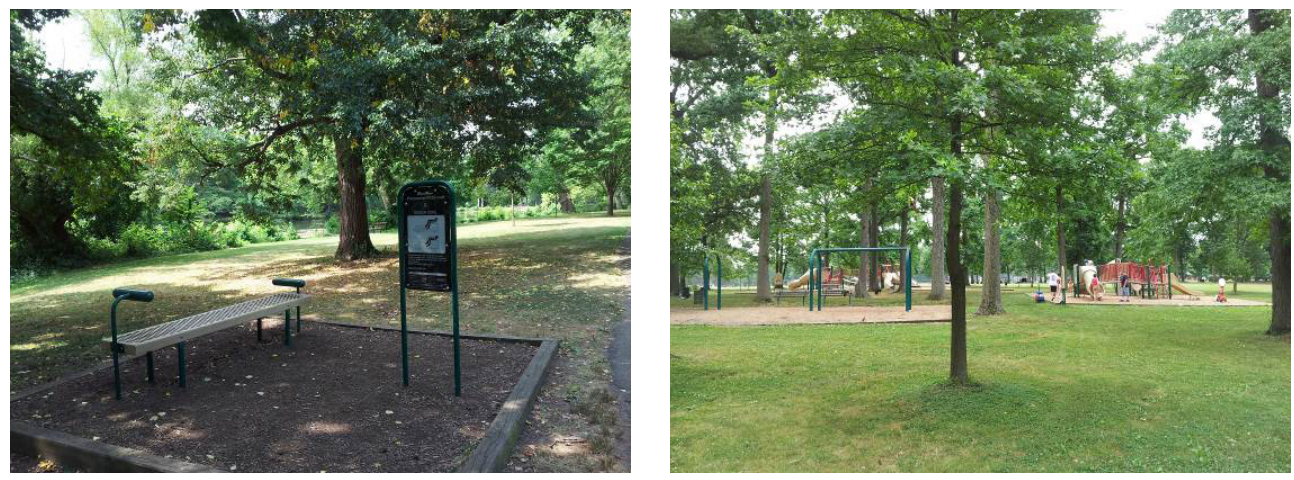

Fig. 5. Rahway River Park - one of the smaller exercise areas. Source: author's photography

Fig. 6. Rahway River Park - play areas. Source: author's photography
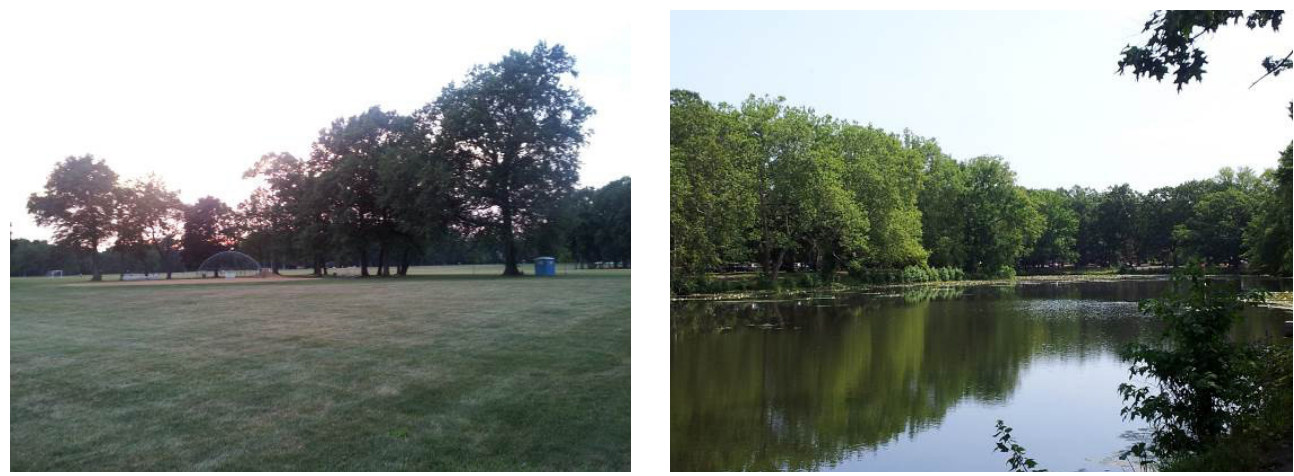

Fig. 7. Rahway River Park - Central open space. Source: Author's photography

Fig. 8. Rahway River Park. Source: Author's photography 


\subsection{Description}

The park was created by the Union County (New Jersey) Parks Commission in 1921 as one of the neighbourhood parks in a county-wide continuous linear park system - Rahway River Parkway. It was designed by landscape architect Percival Gallagher, a partner at the Olmsted Brothers company. The park was created for the enjoyment and psychological health benefits it could provide for its users. This was the original idea of the park commissioners along with the landscape architects, and it represented a shift away from the City Beautiful Movement method of planning; to design more for people's health and well-being.

\subsection{Assessment}

The park was evaluated using the final draft of the universal standard of design for health-promoting places. Both a binary and a detailed assessment were performed. The binary assessment has only 2 categories $(0 ; 1)$ :

$0-$ No, not observed

1 - Yes, satisfactory

The binary assessment is reported under section points (Tables 9-13). The detailed assessment required a written explanation why the researcher thought that the attribute applies. The detailed observation required numerous visits to the park, studying the plans and maps of the park area, as well as scoping the literature evidence. For better clarity, the results of the assessment were grouped into five tables (Tables 9-13).

Rahway River Park was created to protect the natural scenic beauty of the area from development and possible destruction. One of the main early rules of Frederic Law Olmsted (1822-1903) was respect for scenery. This approach is still visible in the park.

The accessibility evaluation was carried out on one road - Parkway Drive - as it is the main access for pedestrians.

The beauty of the park is in the overlapping of nature and recreational activities within its boundaries. There are quiet places to sit and contemplate, observe wildlife or people from a distance. The park houses a variety of sport equipment and recreational amenities, including two circular loops frequented by joggers along with multiple sport fields. 
Table 9. Assessment of Rahway River Park - part 1. Source: author

\begin{tabular}{llc}
\hline & & POINTS \\
\hline 1. SUSTAINABILITY & & $10 / 15$ \\
\hline 1.1.Place & & $-/-$ \\
\hline Area & 124-acre & \\
Location & $\begin{array}{l}\text { The park is cradled by the Rahway River, which serves as } \\
\text { a backdrop and a natural buffer from the nearby houses } \\
\text { to the north and west. The Rahway River Park forms part } \\
\text { of a series of parkways along the Rahway River (Rahway } \\
\text { River Parkway), (Fig. 3). }\end{array}$ \\
\hline Surrounding urban pattern & $\begin{array}{l}\text { Suburban / urban tissue. Rahway River, Rahway River } \\
\text { Cemetery, family houses }\end{array}$ \\
\hline
\end{tabular}

1. 2 Environmental characteristics

\begin{tabular}{|c|c|c|}
\hline Soil quality & $\begin{array}{l}\text { Sufficient for recreational use. } \\
\text { No visible traces of pollution [49]. }\end{array}$ & 1 \\
\hline Water quality & Sub-optimal, according to the Water Quality Report [50]. & 1 \\
\hline Air quality & $\begin{array}{l}\text { Good, according to the Air Quality index (AQI) [51], good } \\
\text { air circulation. The presence of the Rahway River influ- } \\
\text { ences the local microclimate. }\end{array}$ & 1 \\
\hline Noise level & $\begin{array}{l}\text { Moderate noise nuisance comes from traffic in Saint } \\
\text { Georges Street adjacent to the park and slow traffic in Park- } \\
\text { way Drive in the park itself. }\end{array}$ & 1 \\
\hline Forms of natural protection & County park, part of the Rahway River Parkway. & 1 \\
\hline Green and Blue Infrastructure & $\begin{array}{l}\text { It is an important part of the green and blue infrastructure. } \\
\text { The park is a part of the Rahway River Parkway - a green } \\
\text { belt of parkland along the banks of the Rahway River. }\end{array}$ & 1 \\
\hline 1.3.Biodiversity protection & & $2 / 4$ \\
\hline $\begin{array}{l}\text { Parts of open green space not } \\
\text { available to visitors }\end{array}$ & There are no secluded areas for biodiversity protection. & 0 \\
\hline Native plants & Planting is a combination of native and non-native species. & 1 \\
\hline Native animals & Both native and foreign species were observed. & 1 \\
\hline Natural maintenance methods & Data n/a. & 0 \\
\hline \multicolumn{2}{|c|}{ 1.4.Sustainable water management } & $1 / 2$ \\
\hline Rainwater infiltration & Porous, permeable surfaces. Turf used as walkways. & 1 \\
\hline Irrigation with non-potable water & Data n/a. & \\
\hline \multicolumn{2}{|c|}{ 1.5.Parks of Second (New) Generation } & $0 / 1$ \\
\hline & Not observed. & 0 \\
\hline \multirow[t]{2}{*}{ 1.6.Urban metabolism } & & $1 / 1$ \\
\hline & Waste segregation. & 1 \\
\hline 1.7.Ecological energy sources & & $0 / 1$ \\
\hline & Data n/a. & \\
\hline
\end{tabular}


Table 10. Assessment of Rahway River Park - part 2. Source: author

\begin{tabular}{|c|c|c|}
\hline & & POINTS \\
\hline 2. ACCESSIBILITY & & $26 / 26$ \\
\hline \multirow[t]{2}{*}{ 2.1.Distance to park } & & $1 / 1$ \\
\hline & $\begin{array}{l}\text { Most users drive to the park. Some local residents live } \\
\text { within walking distance. }\end{array}$ & 1 \\
\hline \multicolumn{2}{|l|}{ 2.2.Sidewalk Infrastructure- } & $5 / 5$ \\
\hline Width of sidewalk & Sufficient for walking. & 1 \\
\hline Evenness of surface & Sufficient for walking. & 1 \\
\hline Lack of obstructions & Lack of obstructions. & 1 \\
\hline Slope & Flat, no significant slope, (Fig. 4). & 1 \\
\hline Sufficient drainage & Sufficient. & 1 \\
\hline \multicolumn{2}{|c|}{ 2.3.General conditions of walkways } & $8 / 8$ \\
\hline Maintenance & The park is well-maintained. & 1 \\
\hline Overall aesthetics & Satisfactory. & 1 \\
\hline Street art & None. & 1 \\
\hline Sufficient seating & Yes, multiple benches. & 1 \\
\hline Perceived safety & $\begin{array}{l}\text { The park is perceived as a safe place, well-lit and } \\
\text { well-maintained. The police cars are circulating in park } \\
\text { regularly. }\end{array}$ & 1 \\
\hline Buffering from traffic & Sufficient for safety. & 1 \\
\hline Street activities & $\begin{array}{l}\text { There are occasional events, both organised and sponta- } \\
\text { neous. }\end{array}$ & 1 \\
\hline Vacant lots & No, the park is surrounded by the river and residential lots. & 1 \\
\hline 2.4.Traffic & & $5 / 5$ \\
\hline Speed & Slow, traffic limits. & 1 \\
\hline Volume & Moderate to low. & 1 \\
\hline Number and safety of crossings & Numerous possibilities for crossing the street. & 1 \\
\hline Stop signs & Yes, with speed limits. & 1 \\
\hline On-street parking & yes & 1 \\
\hline 2.5.User Experience & & $5 / 5$ \\
\hline Air quality & good & 1 \\
\hline Noise level & Moderate, because of the road. & 1 \\
\hline Sufficient lighting & Yes, numerous lamps. & 1 \\
\hline Sunshine and shadow & Yes. Trees provide shadow. & 1 \\
\hline Visibility of nearby buildings & $\begin{array}{l}\text { Residential properties and fences on one side of the park, } \\
\text { the scenery of the river from other sides. }\end{array}$ & 1 \\
\hline \multirow[t]{2}{*}{ 2.6.Public transport } & & $0 / 1$ \\
\hline & $\begin{array}{l}\text { There are bus stops near the park, but the bus schedule is } \\
\text { not frequent. }\end{array}$ & \\
\hline \multirow[t]{2}{*}{ 2.7.Sufficient Parking } & & $1 / 1$ \\
\hline & $\begin{array}{l}\text { Yes, there are numerous parking spots in the park, as well } \\
\text { as along the streets. }\end{array}$ & 1 \\
\hline
\end{tabular}


Table 11. Assessment of Rahway River Park - part 3. Source: author

\begin{tabular}{|c|c|c|}
\hline \multirow{2}{*}{\multicolumn{2}{|c|}{ 3. AMENITIES }} & POINTS \\
\hline & & $14 / 15$ \\
\hline \multicolumn{2}{|c|}{ 3.1.Psychological and physical rejuvenation } & $5 / 5$ \\
\hline Natural Landscapes & $\begin{array}{l}\text { Natural borders planted with mature trees give an impres- } \\
\text { sion of a pristine natural landscape. }\end{array}$ & 1 \\
\hline Green open space & Extensive grass-covered grounds at the centre of the park. & 1 \\
\hline Presence of water & The Rahway River, a reservoir pond. & 1 \\
\hline Places to rest in the sun and shade & $\begin{array}{l}\text { Multiple places including picnic areas and playgrounds } \\
\text { concealed among the trees. }\end{array}$ & 1 \\
\hline $\begin{array}{l}\text { Places to rest in silence and } \\
\text { solitude }\end{array}$ & Multiple benches to rest in silence and solitude. & 1 \\
\hline 3.2.Physical Activity Promotion & & $3 / 4$ \\
\hline Sports infrastructure & $\begin{array}{l}\text { A track \& soccer field, a baseball field, four softball } \\
\text { pitches, tennis courts, a swimming pool, many loops for } \\
\text { running and walking, (Fig. 5). }\end{array}$ & 1 \\
\hline Recreational infrastructure & Recreational infrastructure for all age groups, (Fig. 6). & 1 \\
\hline Community gardens & No & 0 \\
\hline $\begin{array}{l}\text { Addressing the needs of people } \\
\text { with disabilities }\end{array}$ & $\begin{array}{l}\text { Pathways are wide and even, the majority of the park area } \\
\text { is easy accessible to people with disabilities. }\end{array}$ & 1 \\
\hline 3.3.Catering for basic needs & & $6 / 6$ \\
\hline $\begin{array}{l}\text { Safety and security (presence } \\
\text { of guards, cleanliness, mainte- } \\
\text { nance, etc.) }\end{array}$ & Assessed as a safe place. & 1 \\
\hline Places to sit and rest & Numerous benches. & 1 \\
\hline Shelter & $\begin{array}{l}\text { Multiples shelters, including picnic areas with roofed } \\
\text { shelters. }\end{array}$ & 1 \\
\hline Restrooms & $\begin{array}{l}\text { Yes, two separate units containing restrooms on opposite } \\
\text { sides of the park. }\end{array}$ & 1 \\
\hline Drinking water & Yes, drinking fountains, refreshment stands. & 1 \\
\hline $\begin{array}{l}\text { Food (possibility to buy food in } \\
\text { the park or close vicinities) }\end{array}$ & Snack bar, Food Stands, occasionally food trucks. & 1 \\
\hline
\end{tabular}


Table 12. Assessment of Rahway River Park - part 4. Source: author

\begin{tabular}{|c|c|c|}
\hline & & POINTS \\
\hline 4. DESIGN & & $19 / 21$ \\
\hline 4.1.Architectural design & & $10 / 10$ \\
\hline Human scale & $\begin{array}{l}\text { The entire neighbourhood respects human scale; park inte- } \\
\text { riors are cosy thanks to design and tree canopy. (Fig. 7-8) }\end{array}$ & 1 \\
\hline $\begin{array}{l}\text { Architectural variety of urban } \\
\text { environment }\end{array}$ & Single-family individual houses. & 1 \\
\hline Focal points and landmarks & Clear landmarks. & 1 \\
\hline Structure of interior connections & A clear structure of interior connections. & 1 \\
\hline Framed views & $\begin{array}{l}\text { Natural frames are created by the trunks and canopy of } \\
\text { mature trees. }\end{array}$ & 1 \\
\hline Long vistas (Extent) & Yes, the park offers numerous extensive vistas. & 1 \\
\hline Pathways with views & $\begin{array}{l}\text { Yes, the path along Parkway Drive provides interesting } \\
\text { views. }\end{array}$ & 1 \\
\hline $\begin{array}{l}\text { Invisible parts of the scenery } \\
\text { (Vistas which engage } \\
\text { the imagination) }\end{array}$ & $\begin{array}{l}\text { Yes, numerous designed vistas that engage the imagination, } \\
\text { (Fig. 9-10). }\end{array}$ & 1 \\
\hline $\begin{array}{l}\text { Possibility to observe other } \\
\text { people }\end{array}$ & $\begin{array}{l}\text { Plenty of places to watch the activities of other people from } \\
\text { a distance - sport competitions, people running, children } \\
\text { playing, etc. }\end{array}$ & 1 \\
\hline Possibility to observe animals & $\begin{array}{l}\text { Plenty of places to see wildlife from a distance - wild } \\
\text { goose and other birds, squirrels, small animals, colourful } \\
\text { insects - e.g., butterflies, etc. }\end{array}$ & 1 \\
\hline 4.2.Salutogenic design & & $4 / 5$ \\
\hline Optimal level of complexity & $\begin{array}{l}\text { Yes, the park was designed to offer both legible } \\
\text { composition and optimal level of complexity, (Fig. 7-8). }\end{array}$ & 1 \\
\hline Engaging features & $\begin{array}{l}\text { There are multiple elements which attract attention, e.g., } \\
\text { wildlife, running water in the river, greenery, presence of } \\
\text { other users. }\end{array}$ & 1 \\
\hline Controlled Risk & $\begin{array}{l}\text { Several elements offer a subjective feeling of overcoming } \\
\text { controlled risk, e.g., walking along the river. }\end{array}$ & 1 \\
\hline Mystery/Fascination & no & 0 \\
\hline Movement & Flowing river water, shimmering greenery. & 1 \\
\hline 4.3.Sensory stimuli design & & $5 / 6$ \\
\hline Sensory stimuli: Sight & $\begin{array}{l}\text { Some elements such as colourful leaves in the autumn, } \\
\text { flowers in the warm season. }\end{array}$ & 1 \\
\hline Sensory stimuli: Hearing & Sound of water in the river. & 1 \\
\hline Sensory stimuli: Smell & Flowers in the warm season. & 1 \\
\hline Sensory stimuli: Touch & Trees, water, snow in the cold season. & 1 \\
\hline Sensory stimuli: Taste & Refreshment stands, snack bar. & 1 \\
\hline Sensory path & no & 0 \\
\hline
\end{tabular}


Table 13. Assessment of Rahway River Park - part 5. Source: author

\begin{tabular}{|c|c|c|}
\hline & & POINTS \\
\hline 5. PLACEMAKING & & $10 / 14$ \\
\hline 5.1.Social Contact Enhancement & & $2 / 2$ \\
\hline Organization of events & $\begin{array}{l}\text { Organized events, sports competition - softball, baseball, } \\
\text { etc., cultural events, food truck days, etc. }\end{array}$ & 1 \\
\hline Meeting places for groups & $\begin{array}{l}\text { Multiple picnic areas, roofed gazebos with amenities, open } \\
\text { green space used for informal gatherings, etc. }\end{array}$ & 1 \\
\hline 5.2.Human perception - spiritual & \& symbolic & $2 / 6$ \\
\hline Sacred places & no & 0 \\
\hline Works of Art & no & 0 \\
\hline Monuments & $\begin{array}{l}\text { The Horsehead Copper Monument is located on St. Georges } \\
\text { Ave. across the Rahway River Park. Revolutionary War Site } \\
\text { Marker - St. Georges Avenue outside Rahway River Park. } \\
\text { The Historical Rahway Cemetery located next to Rahway } \\
\text { River Park. }\end{array}$ & 1 \\
\hline $\begin{array}{l}\text { Culture and connections to the } \\
\text { past }\end{array}$ & $\begin{array}{l}\text { A bench with a commemorative plaque is dedicated to the } \\
\text { memory of park founder Arthur Rindge Wendell. It can be } \\
\text { found in the Rahway River Park facing the lake. }\end{array}$ & 1 \\
\hline Thematic gardens & No & 0 \\
\hline Personalisation & No & 0 \\
\hline 5.3.Community Engagement & & $6 / 6$ \\
\hline $\begin{array}{l}\text { Personalising the architectural } \\
\text { process }\end{array}$ & $\begin{array}{l}\text { The authors of the design - Olmsted brothers were } \\
\text { well-known landscape architects. }\end{array}$ & 1 \\
\hline $\begin{array}{l}\text { Participation of all stakeholders, } \\
\text { including inhabitants and users }\end{array}$ & $\begin{array}{l}\text { All stakeholders, including inhabitants and users have a real } \\
\text { influence on the design and maintenance of the park. }\end{array}$ & 1 \\
\hline $\begin{array}{l}\text { Determining the rules of conduct } \\
\text { and self- management }\end{array}$ & $\begin{array}{l}\text { There are information boards with rules of conduct and } \\
\text { self-management placed in well-visible places. }\end{array}$ & 1 \\
\hline Space for social contacts & $\begin{array}{l}\text { There are inclusive, accessible space for social contacts } \\
\text { available to all (picnic areas, roofed gazebos with amenities } \\
\text { for reunions, etc.) Park is often used for organising family } \\
\text { reunions. }\end{array}$ & 1 \\
\hline third places & It is a third place for some parkgoers. & 1 \\
\hline fourth places & It is a fourth place for occasional users & 1 \\
\hline
\end{tabular}




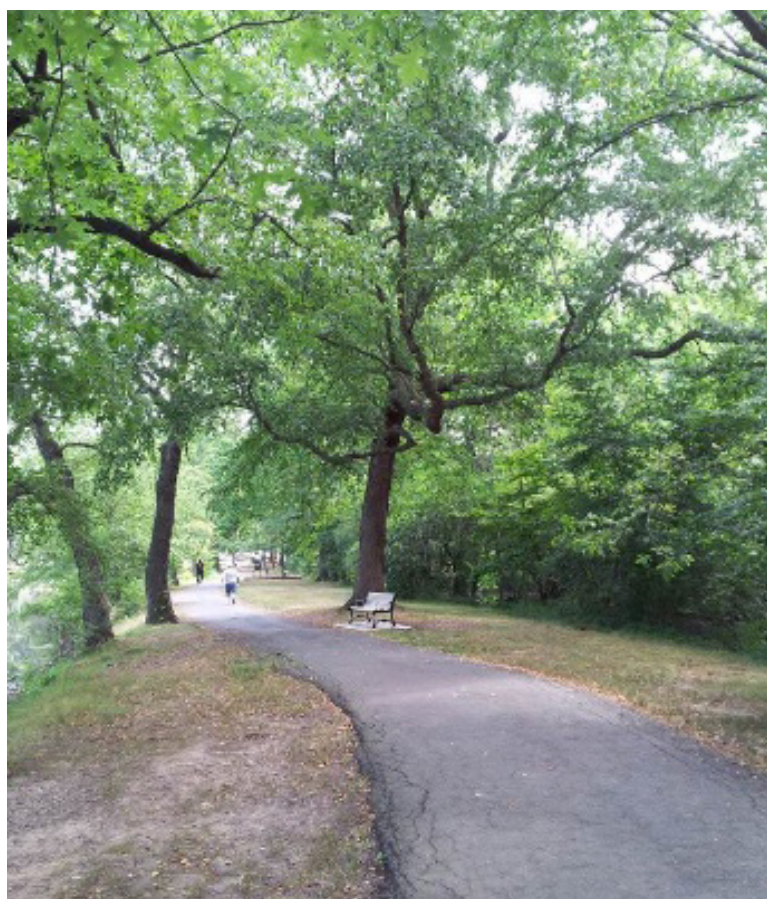

Fig. 9. Rahway River Park -walking and jogging loop. Source: author's photography

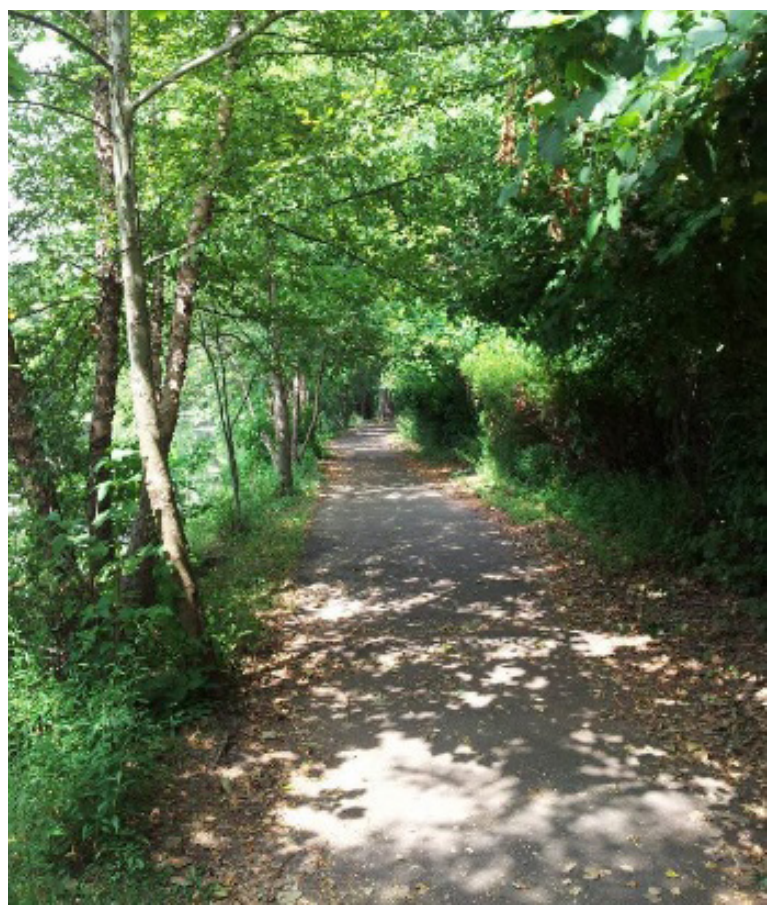

Fig. 10. Rahway River Park - one of the paths. Source: author's photography 


\section{Discussion}

Nowadays, city residents need the contact with nature more than ever due to rapid urbanisation and shrinking areas of natural habitats. The results of numerous studies showed that regular visits to urban parks can stimulate the mental and physical regeneration, create social bonds, and facilitate physical activities.

Rahway River Park - built a hundred years ago to promote the health and well-being of Union County inhabitants - scored $86 \%$, that is 79 out of a maximum 91 points. This result indicates that this is a health-promoting place. The universal standard method used in this research has helped to distinguish the material, social, spiritual \& symbolic qualities of the park. Addressing the points that were missing, as observed by the author, might help to make the park more welcoming to people who are seeking a spiritual retreat, horticultural therapy sessions, sensory paths, etc.

There are limitations to this Universal Standard, because it is tainted by the subjectivity of perception. For example, section 4. - Design - includes points that require a more subjective assessment. The simplified scale does not allow for the evaluation of the quality and intensity of a given attribute. To mitigate this drawback, the binary assessment used here $(0,1)$ could be replaced with numerical grades (e.g. $0-10$ or $0-100 \%$ ), which would allow for more precise assessment of given attributes. In the case of more detailed assessments, the problem of subjectivity may be slightly mitigated with more comprehensive descriptions of the assessed attributes.

Previous work addressed the physical activity infrastructure and sustainable solutions assessment, but it did not provide the methods for measurement of therapeutic qualities of POS. This universal standard could be used to evaluate and justify the design choices of public open green spaces (POS). It was developed after scoping literature review and on site observation of over a 100 of POS in various countries in Europe and the USA.

The main identified limitation in its use stems directly from the subjectivity of perception during assessment. While many therapeutic attributes can be assessed objectively, some are more subjective due to the fact that perception of therapeutic landscapes may vary. Therefore, this universal model should not be used as a tool for statistical comparison of therapeutic values of different parks, but rather as an assessment tool. The subjectivity of assessments could be mitigated by providing more detailed descriptions of specific attributes or assessments by a team of researchers.

\section{Conclusions}

This paper presents a universal standard for health-promoting places. It was developed using an iterative process, after a long-term study of over a hundred public parks and therapeutic gardens located in Europe and the USA. The case study of Rahway River Park demonstrates that the proposed standard can be successfully used to identify the health-promoting qualities of an open green space and to find the areas for improvement.

The universal standard presents a significant advancement in the field of research of urban design and landscape architecture, because it merges an evidence-informed approach with systematic field study. This universal standard is a valuable tool based on research evidence (EBD) and post occupancy evaluation (POE). It could be used to facilitate decision making, justify choices, and incorporate research evidence into urban planning. It could also help in the design of therapeutic POS, as well as support other strategies for urban regeneration. 
This universal model should be developed further, for example by including new attributes or determining which of the attributes should become mandatory prerequisites. COVID19 by forcing social distancing and lockdowns emphasized the need for open urban green spaces. Remote work from home, unemployment, and health insecurity can increase stress level. Open green spaces should provide the opportunity for mental and physical restoration, physical activities, and allow for at least a bit of social contact. Public parks have become a refuge during the time when many sports and recreational facilities were closed. The criteria 2.1 Accessibility, Distance to a park and a question: Is it possible to walk to a park? proved to be the most important during the confinement when it was not possible to use public transport.

As the research was conducted in only a few regions of the Northern Hemisphere, further studies in the wider community may be required, as well as further validation, discussion, and development, in order for it to become a truly universal tool.

Funding: This research received no external funding.

Conflicts of Interest: The authors declare no conflict of interest.

\section{References}

[1] Frumkin H., "Beyond toxicity: human health and the natural environment", American journal of preventive medicine, vol. 20, no.3, (2001), pp.234-40. https://doi.org/10.1016/ S0749-3797(00)00317-2

[2] Largo-Wight E., "Cultivating healthy places and communities: evidenced-based nature contact recommendations", International Journal of Environmental Health Research, vol. 21, no. 1, (2011), pp. 41-61. https://doi.org/10.1080/09603123.2010.499452

[3] Frumkin H. et al., "Nature Contact and Human Health: A Research Agenda", Environmental Health Perspectives, vol 125, no. 7, (2017). https://doi.org/10.1289/EHP1663

[4] Gesler W., "Lourdes: healing in a place of pilgrimage", Health \& Place, vol. 2, no.2, pp. 95-105, (1996). https://doi.org/10.1016/1353-8292(96)00004-4

[5] Zube E., "Perceived land Use Patterns and Landscape Values", Landscape Ecology, vol. 1, no. 1, (1987), pp 37-45. https://doi.org/10.1007/BF02275264

[6] Williams A., "Therapeutic landscapes in holistic medicine", Social Science and Medicine, vol. 46, no. 9, (1998), pp. 1193-1203. https://doi.org/10.1016/S0277-9536(97)10048-X

[7] Bell S. L., Wheeler B. W., Phoenix C., "Using Geonarratives to Explore the Diverse Temporalities of Therapeutic Landscapes: Perspectives from "Green" and "Blue" Settings", Annals of the American Association of Geographers, vol. 107, no. 1, (2017), pp. 93-108. https://doi.org/10.10 80/24694452.2016.1218269

[8] Gesler W., "Therapeutic Landscapes: An evolving theme”, Health \& Place, vol. 11, no. 4, (2005), pp. 295-297. https://doi.org/10.1016/j.healthplace.2005.02.003

[9] Williams A., "Spiritual therapeutic landscapes and healing: A case study of St. Anne de Beaupre, Quebec, Canada", Social Science \& Medicine, vol. 70, no. 10, (2010), pp. 1633-1640. https://doi. org/10.1016/j.socscimed.2010.01.012

[10] Cooper-Marcus C., Sachs N., Therapeutic Landscapes. An Evidence-Based Approach to Designing Healing Gardens and Restorative Outdoor Spaces. Hoboken, New Jersey: John Wiley \& Sons, Inc., 2014, pp. 14-35.

[11] Huang L., Xu H., "Therapeutic landscapes and longevity: Wellness tourism in Bama”, Social Science \& Medicine, vol. 197, (2017), pp. 24-32. https://doi.org/10.1016/j.socscimed.2017.11.052

[12] Trojanowska M., Sas-Bojarska A., "Health-affirming everyday landscapes in sustainable city. Theories and tools", ACEE Architecture Civil and Environmental Engineering, no. 3/2018, (2018). https://doi.org/10.21307/ACEE-2018-037 
[13] Bell S.L., Foley R., Houghton F. et al., "From therapeutic landscapes to healthy spaces, places and practices: A scoping review", Social Science \& Medicine, vol. 196, (2018), pp. 123-130. https:// doi.org/10.1016/j.socscimed.2017.11.035

[14] Williams A., "Spiritual therapeutic landscapes and healing: A case study of St. Anne de Beaupre, Quebec, Canada", Social Science \& Medicine, , vol. 70, no. 10 pp. 1633-1640. https://doi. org/10.1016/j.socscimed.2010.01.012

[15] Huang L., Xu H., "Therapeutic landscapes and longevity: Wellness tourism in Bama", Social Science \& Medicine, vol. 197, (2018), pp. 24-32. https://doi.org/10.1016/j.socscimed.2017.11.052

[16] Harting T., Bringslimark T., Patil GG. "Restorative Environmental Design: What, When, Wher, and for Whom?" in: Biophilic design: the theory, science, and practice of bringing buildings to life, Kellert S., Heerwagen J., Mador M. (Ed.), (2008), Hobken, New Jersey: John Wiley \& Sons, pp. 133.

[17] Community green: using local spaces to tackle inequality and improve health, London, CABE Commission for architecture and the built environment, (2010).

[18] Ulrich, R., "View through a window may influence recovery from surgery". Science, Vol. 224, No. 4647, (1984), pp. 42-421. https://doi.org/10.1126/science.6143402

[19] Kaplan R., Kaplan S., Ryan R.L. With People in Mind. Design and Management of Everyday Nature Island Press, Washington D.C., Covelo, California, 1998.

[20] Rosenblatt Naderi J., "Design of walking environments for spirituals renewal Paper presented to Walk21-V Cities for people", in Proceedings - The fifth International Conference on Walking in the 21st century, June 9-11 2004, Copenhagen, Denmark.

[21] Heerwagen J., Gregory B., "Biophilia and Sensory Aesthetics", in: Biophilic design: the theory, science, and practice of bringing buildings to life, Kellert S., Heerwagen J., Mador M. (Ed.), Hoboken, New Jersey: John Wiley \& Sons, 2008.

[22] Mahan A., Golestani S., Meschi M., "Pedestrian street and walkability: Studying the effect of type and quality of adjacent usage in walkability of pedestrian street", in: Dymitryszyn I., Kaczyńska M., Maksymiuk G.: The power of landscape- Peer Reviewed Proceedings of ECLAS 2012 Conference at Warsaw University of Life Science - SGGW, 2012.

[23] Ryan C., Browning W., Clancy J., "Biophilic Design Patterns Emerging Nature-Based Parameters for Health and Well-Being in the Built Environment", International Journal of Architectural Research, Vol. 8, No. 2, (2014), pp. 62-76. https://archnet.org/publications/9767

[24] Hildebrand G., "Biophilic Architectural Space: In: Kellert S., Heerwagen J., Mador M. (Ed.), 2008 Biophilic design: the theory, science, and practice of bringing buildings to life, Hoboken, New Jersey: John Wiley \& Sons, 2008.

[25] Kuo F., Sullivan W., "Environment and crime in the inner city. Does Vegetation Reduce Crime?", Environment and Behavior, vol. 33, no. 3, (2001), pp. 343-367. https://doi. org/10.1177/0013916501333002

[26] Kuo F., Parks and Other Green Environments: Essential Components of a Healthy Human Habitat. National Recreation and Park Association, 2010. Available: https://www.nrpa.org/globalassets/ research/mingkuo-research-paper.pdf [Accessed: 29 Mar 2020]

[27] Sempik, J., Aldridge, J., Becker, S., Growing Together - a practice guide to promoting social inclusion through gardening and horticulture, Bristol: The Policy Press, 2005.

[28] Sempik J., Aldridge J., Becker S., Health, Well-being and Social Inclusion Therapeutic Horticulture in the UK. Bristol: The Policy Press, 2005.

[29] Mass J. van Dillen, S.M.E., Verheij, R.A., \& Groenewegen, "Social contacts as possible mechanism behind the relation between Green space and health", Health and Place, Vol. 15, No. 2, (2009), pp. 586-595. https://doi.org/10.1016/j.healthplace.2008.09.006 
[30] Ghavampour E., The contribution of Natural Design Elements to the Sustained Use of Public Space in a City Centre. Ph.D. desideration, University of Wellington, 2014.

[31] Marques B., McIntosh J., Chanse V., "Improving Community Health and Wellbeing Through Multi-Functional Green Infrastructure in Cities Undergoing Densification", Acta Horticulturae et Regiotecturae, vol.23, no.2, (2020), pp.101-107. https://doi.org/10.2478/ahr-2020-0020

[32] Gehl J., Life Between Buildings: Using Public Space. Island Press; Sixth Edition, 2011.

[33] Grahn P. et al., "A planning model for designing sustainable and healthy cities. The importance of people's need of recreational environments in an urban context", in: NAEP (National Assoc. of Environmental Professionals) 30 th Annual Conference, Alexandris VA, USA, 16-19 april 2005

[34] Lis A., Struktura podtoża motywacyjnego zachowań użytkowników parków miejskich. Wrocław: Wydawnictwo Akademii Rolniczej we Wrocławiu, 2005.

[35] Stigsdotter, U. A. and Grahn, P., 'What Makes a Garden a Healing Garden?', Journal of Therapeutic Horticulture, Vol. 13, (2002), pp. 60-69.

[36] Alexander Ch., A pattern language. Towns-Buildings- Construction. Oxford University Press, 1977.

[37] Ward J.S. Duncan J.S. Jarden A. Steward T., "The impact of children's exposure to greenspace on physical activity, cognitive development, emotional wellbeing, and ability to appraise risk.", Health \& Place, vol. 40, (2016), pp. 44-50. https://doi.org/10.1016/j.healthplace.2016.04.015

[38] Takano T, Nakamura K., Watanabe M., 'Urban residential environments and senior citizens' longevity in megacity areas: the importance of walkable green spaces", Journal of Epidemiology Community Health; vol. 56, (2002), pp. 913-918. https://doi.org/10.1136/jech.56.12.913

[39] Gibson J., The Ecological Approach to Visual Perception. 1st Edition, Routlege, 2014.

[40] Stoltz J., Schaffer Ch., "Salutogenic Affordances and Sustainability: Multiple Benefits With Edible Forest Gardens in Urban Green Spaces", Frontiers in Psychology, (2018). https://doi.org/10.3389/ fpsyg.2018.02344

[41] Souter-Brown G., Hinckson E., Duncan S., "Effects of a sensory garden on workplace wellbeing: A randomised control trial", Landscape and Urban Planning, vol. 207, (2021). https://doi. org/10.1016/j.landurbplan.2020.103997

[42] Stone B., Perez-Carro C., Activity-Based Parks Typology: A Strategy for Addressing the Parks and Recreation Needs of Residents in an Urban Environment. Option paper, CP 8990, spring 2015. Available: https://smartech.gatech.edu/bitstream/handle/1853/53792/perez_carlos_activity_based_parks_typology.pdf?sequence=1\&isAllowed=y [Accessed: 29 Mar 2020]

[43] Trojanowska M., Parki i ogrody terapeutyczne. Warszawa: Wydawnictwo Naukowe PWN, 2017.

[44] Trojanowska M., "Therapeutic Qualities and Sustainable Approach to Heritage of the City. The Coastal Strip in Gdańsk, Poland”, Sustainability, vol. 12, no. 21, (2020). https://doi.org/10.3390/ su12219243

[45] Trojanowska M., "Architectural strategies that promote creation of social bonds within eco-neighbourhoods", Space and Form, no. 46/2021, (2020), pp.195-210. https://doi.org/10.21005/ pif.2021.46.C-07

[46] Day S., "Place and the experience of air quality", Health \& Place, Vol. 13, No.1, (2007), pp. 249-260, https://doi.org/10.1016/j.healthplace.2006.01.002

[47] Zuniga-Teran A. et al., "Designing healthy communities: Testing the walkability model", Frontiers of Architectural Research, Vol. 6, No. 1, (2016), pp.63-73. https://doi.org/10.1016/j.foar.2016.11.005

[48] Burypensions, "UCCF 4/16/15: Rahway River Park Stadium Full Coverage", countywatchers. Available: https://countywatchers.wordpress.com/2015/04/18/uccf-41615-rahway-river-parkstadium-full-coverage/ [Accessed: 18 Oct 2021] 
[49] United State Department of Agriculture, Soil Survey or Union County, New Jersey, 2002. Available: https://www.nrcs.usda.gov/Internet/FSE_MANUSCRIPTS/new_jersey/unionNJ2002/ unionNJ2002.pdf [Accessed: 29 Mar 2020]

[50] Rahway River Watershed Association, 2018 Water Quality Report Card, 2018. Available: https://rahwayriver.org/waterqualitydocs/RRWA2018Water\%20QualityReportCard.pdf [Accessed: 29 Mar 2020]

[51] IQAir, Air quality in Rahway. Available: https://www.iqair.com/usa/new-jersey/rahway [Accessed: 29 Mar 2020] 